\title{
The Effect of Sodium Valproate on the Glioblastoma U87 Cell Line Tumor Development on the Chicken Embryo Chorioallantoic Membrane and on EZH2 and p53 Expression
}

\author{
Dovilè Kavaliauskaitè, ${ }^{1}$ Donatas Stakišaitis, ${ }^{1,2}$ Justè Martinkutè, ${ }^{1}$ Lina Šlekienè, ${ }^{1}$ \\ Arūnas Kazlauskas, ${ }^{3}$ Ingrida Balnytė, ${ }^{1}$ Vaiva Lesauskaitė, ${ }^{4}$ and Angelija Valančiūtė ${ }^{1}$ \\ ${ }^{1}$ Department of Histology and Embryology, Lithuanian University of Health Sciences, Mickeviciaus Str., LT-44307 Kaunas, Lithuania \\ ${ }^{2}$ Laboratory of Cancer Epidemiology, National Cancer Institute, Santariškiu Str. 1, LT-08660 Vilnius, Lithuania \\ ${ }^{3}$ Lithuanian University of Health Sciences, Neuroscience Institute, Laboratory of Neurooncology and Genetics, \\ Eiveniu 4, LT-50161 Kaunas, Lithuania \\ ${ }^{4}$ Lithuanian University of Health Sciences, Institute of Cardiology, Laboratory of Molecular Cardiology, Suklileliu 17, \\ LT-50161 Kaunas, Lithuania
}

Correspondence should be addressed to Angelija Valančiūté; angelija.valanciute@lsmuni.lt

Received 20 February 2017; Revised 18 April 2017; Accepted 7 May 2017; Published 31 May 2017

Academic Editor: Sara Piccirillo

Copyright (C) 2017 Dovile Kavaliauskaite et al. This is an open access article distributed under the Creative Commons Attribution License, which permits unrestricted use, distribution, and reproduction in any medium, provided the original work is properly cited.

\begin{abstract}
Literature data support evidences that glioblastoma (GBM) patients experience prolonged survival due to sodium valproate (NaVP) treatment. The study assessed the human GBM cell U87 xenograft studied in the chicken embryo chorioallantoic membrane (CAM) model evaluating NaVP effect on tumor. Three groups of tumors (each $n=10$ ) were studied: nontreated, treated with $4 \mathrm{mM}$, and treated with $8 \mathrm{mM}$ of NaVP. The majority of tumors without NaVP treatment during tumor growth destroyed the chorionic epithelium, invaded the mesenchyme, and induced angiogenesis. Incidence of tumor formation on CAM without invasion into the mesenchyme was higher when U87 cells were treated with NaVP; the effect significantly increased with NaVP concentration. Treatment with $8 \mathrm{mM}$ of NaVP did not show clear dynamics of tumor growth during 5 days; at the same time, the angiogenesis failed. With a strong staining of EZH2, p53 in tumors without NaVP treatment was found, and NaVP significantly decreased the expression of EZH2- and p53-positive cells; the effect was significantly higher at its $8 \mathrm{mM}$ concentration. NaVP has a function in blocking the growth, invasion, and angiogenesis of tumor in the CAM model; tumor growth interferes with EZH2 and p53 molecular pathways, supporting the NaVP potential in GBM therapy.
\end{abstract}

\section{Introduction}

Glioblastoma multiforme (GBM) is the most frequent, highly recurrent, and rapidly progressing type of astrocytic brain tumor in adults [1]. Epileptic seizures occur in approximately $50 \%$ of GBM patients $[2,3]$. Sodium valproate $(\mathrm{NaVP})$ is an authorized medicinal product for the treatment of epileptic seizure, migraine, neuralgia, and bipolar disorder $[4,5]$. Glioma patients with a history of seizures have a better prognosis than patients without seizures and it has been reported that this phenomenon could be related to the NaVP used for seizure prophylaxis or treatment. The meta-analysis of studies data also supports the evidence that glioblastoma patients experience prolonged survival due to NaVP treatment $[6,7]$.

The mechanisms of NaVP without an antiepileptic activity are the known inhibitor of histone deacetylase [4]. It has an anticancer effect in several human GBM cell lines [8]. Preclinical studies have suggested that NaVP could affect tumor cells by inhibiting DNA methyltransferase [9], cellular kinases, modulating the MAPK signaling pathway [10]. NaVP shows antineoplastic activity based on its gene-regulation functions [11-13]; it has an effect on chloride, sodium ions transport in vivo [14], induces cell cycle arrest, and enhances 
the efficiency of glioma radiotherapy in clinical trials [15]. $\mathrm{NaVP}$ has been reported to have an anticancer effect on U87 cells at low dosages of the drug [8]. NaVP is able to induce apoptosis in glioma U87 cells in a dose-dependent manner through the activation of the mitochondria apoptosis pathway [16].

Further studies of GBM markers are needed to know how NaVP regulates tumor growth in experimental models. Polycomb group proteins (PRC1 and PRC2) regulate the chromatin structure and have an important regulatory role in human malignancies and catalyze histone ( $\mathrm{H} 2 \mathrm{~A}$ and $\mathrm{H} 3$ ) modifications. Studies show the role of the PRC2 catalytic component enhancer of the zeste homolog 2 (EZH2) in neoplastic development [17]. EZH2 is actively involved in cell cycle progression, cell proliferation, differentiation, and apoptosis which are associated with human malignancy progression $[17,18]$. EZH2 in glioblastoma leads to cell cycle arrest at the $G_{0} / G_{1}$ phase [19]. The EZH2 protein was found to be well expressed in U87 cell lines and its increased expression in human glioma tissue correlates with the glioma grade and a decreased GBM patient survival [20]. The EZH2 protein participates in mice embryo development [21]. EZH2 promotes the epithelial to mesenchymal transition program $[22,23]$. EZH2 inhibitors have been an area of intense preclinical and clinical investigations and show a significant antitumor effect in various malignancies in animal models $[24,25]$.

The tumor suppressor gene $p 53$ is a cell cycle regulator protein associated with the suspension of cell growth and apoptosis induction [26]. Recently the p53 protein has been found to regulate cellular metabolism, stem cell function, invasion, metastases, and cell-cell communication within the tumor microenvironment [27]. Studies of $\operatorname{Trp}^{-1-} 3^{-/} \mathrm{Pen}^{-/-}$ mice showed that p53 promotes glioblastoma cells differentiation and inhibits the tumor development [28]. The tumor $p 53$ has a potential noncell autonomous function by modulating the expression of secreted proteins influencing the neighbor cells [29]. The loss of normal p53 function and the acquisition of oncogenic functions by mutant p53 proteins may contribute to tumorigenesis. The role of p53 in glioma progression is under ongoing discussion as the overexpression of mutated p53 may mark more aggressive tumor biology [30]. The expression of the protein p53 had a significant impact on the survival time: patients who did not have immunohistochemical expression of p53 had a significantly longer median survival time than those with its positive expression [31], but other researchers did not found opposite relationship [32]. The expression of p53 in the human glioma U87 cell line nuclei was found to depend on the used animal model: the percentage of human glioblastoma p53-positive nuclei of the same xenograft was higher in the tumors grown on the chick chorioallantoic membrane than in the brain of nude rat model [33].

The first-line treatment drug Temozolomide for GBM may only increase the survival of patients on average by a few months, and NaVP treatment sensitizes temozolomideresistant glioma cells [8, 34]. Thus, it is urgently needed to develop novel strategies to increase the efficacy of the
GBM treatment. The present study was designed to assess the human glioma cell U87 xenograft studied in the chicken embryo chorioallantoic membrane (CAM) model. CAM is widely used as an in vivo model for the investigation of tumor invasion, metastasis, and neoangiogenesis [35, 36]; also it is valuable model to study drug delivery systems [37]. CAM is a highly vascularized membrane located beneath egg shell and serves for metabolic exchange between air and chick embryo [38]. Chick embryo develops in 21 days until hatching and immune system matures completely only at the 18th embryo day development (EDD) [39]. The macroscopic tumor appearance, histopathology, and the immunohistochemistry of U87 cells untreated and treated with different $\mathrm{NaVP}$ concentrations as well as the expression of the selected p53 and EZH2 markers in xenograft tumor were tested.

The main objectives which indicate the novel and original aspects of the current study were to compare the evaluated characteristics of the tumor growth, penetration to the CAM mesenchyme, and correlation of these phenomena with the $\mathrm{EZH} 2$ and p53 expression in the tumor as a response to the treatment with different $\mathrm{NaVP}$ concentrations in the CAM model.

\section{Materials and Methods}

2.1. Egg Preparation for the Inoculation of Tumor Cells and the Study Groups. Fertilized chicken eggs (Cobb 500) were purchased from a local hatchery and incubated (Maino incubators, Oltrona S.M. (Co), Italy) for 7 days after breeding at $37^{\circ} \mathrm{C}$ and $60 \%$ humidity. For three consecutive days the eggs were rolled in an incubator once per hour. Then the eggs were cleaned with prewarmed $70 \%$ ethanol and a small hole was drilled in the location of an air sac. Approximately $2 \mathrm{ml}$ of albumin was aspirated to create a false air sac directly over the CAM, allowing its dissociation from the egg shell membrane. Then a square window of approximately $1 \mathrm{~cm}^{2}$ was carefully drilled, opened, and sealed with sterile parafilm for the further inoculation of tumor cells. The eggs were then sealed with a transparent tape and returned back into the incubator until tumor cell grafting [40]. The cells were grafted on the 7 th day of embryogenesis. Three fertilized chicken egg groups were studied: (1) nontreated (control) $(n=10),(2)$ treated with a $4 \mathrm{mM}$ of $\mathrm{NaVP}(n=10)$, and (3) treated with $8 \mathrm{mM}$ of $\mathrm{NaVP}(n=10)$.

2.2. U87 Cell Placement on the CAM. Commercial human glioblastoma U87 cells line was obtained from the Institute of Neuroscience (Kaunas, Lithuania) and kept in Dulbecco's modified Eagles medium (DMEM) (Gibco, USA) supplemented with $10 \%$ fetal bovine serum (Gibco, USA) and with $100 \mathrm{IU} / \mathrm{mL}$ of penicillin and $100 \mu \mathrm{g} / \mathrm{mL}$ streptomycin (Gibco, USA). The amount of $1 \times 10^{6}$ U87 cells was resuspended in $10 \mu$ l of the DMEN (1x) + GlutaMAX (GIBCO, USA). These cells (in $10 \mu \mathrm{l}$ of the medium) were mixed with $10 \mu$ l type I rat tail collagen (Gibco, USA) commonly used to form visible tumors on the chicken embryo chorioallantoic membrane. The total amount of $20 \mu \mathrm{l}$ of the mixture was then dropped onto an absorbable surgical sponge (Surgispon ${ }^{\circledR}$ ) which was 
cut by hand with a blade into equal pieces of $9 \mathrm{~mm}^{3}(3 \times 3 \times$ $1 \mathrm{~mm}$ ). Each piece of the sponge (one per embryo) was later gently placed on the top of the growing CAM on the day 7 (EDD7) of embryo development $(n=30)$.

The NaVP-treated and control specimens were collected after 5 days of incubation on the 12 days of embryo development (EDD12), fixed in a buffered $10 \%$ formalin solution for $24 \mathrm{~h}$ and then paraffin-embedded.

2.3. Haematoxylin and Eosin (H-E) Staining. Each embryo of different experimental groups was sacrificed and a CAM was removed, fixed in $10 \%$ neutral-buffered formalin, dehydrated, and embedded in paraffin. Serial sections of $3 \mu \mathrm{m}$ were cut and stained using the standard $\mathrm{H}-\mathrm{E}$ technique. After overnight incubation at $37^{\circ} \mathrm{C}$ the sections were deparaffinized in xylene, dehydrated in graded series of ethanol $(70 \%, 90 \%$, and $96 \%$ ), stained with $\mathrm{H}-\mathrm{E}$, and then cleared with xylene and mounted using a mounting medium (Roti ${ }^{\circledR}$-Histokitt II, Germany).

2.4. Biomicroscopy In Vivo and Light Microscopy for the Visualization of Formed Tumors In Vivo. CAMs with grafted U87 cells were registered in vivo daily under a stereomicroscope (SZX2-RFA16, Japan) equipped with an Olympus DP72 camera for both video recordings and acquiring still images. CAMs were investigated from day 2 (EDD9) after grafting to day 5 (EDD12). Histological slides were investigated under a light microscope Olympus BX40F4 (Olympus Optical Co. $L t d$., Japan) and photographed with an Olympus digital camera (XC30, Japan) using CellSens Dimension 1.9 Digital Imaging Software.

2.5. Immunohistochemistry and Cell Count. Paraffin blocks of CAM with grafted tumors were cut into $3 \mu \mathrm{m}$ slices and then processed using standard deparaffinization and rehydration techniques. The polyclonal anti-KMT6/EZH2 (phospho S21, ab84989, Abcam) and monoclonal anti-p53 (aa 211-220, clone240, CBL404, Millipore) antibodies were used as the primary antibodies to detect positively stained U87 cells. The primary antibody was detected using biotinylated secondary antibody (DAKO EnVision Flex + Mouse) followed by horseradish peroxidase-conjugated streptavidin (DAKO EnVision Flex/HRP) used as recommended by the manufacturer. Finally, positive reactions were visualized using a 3,3'-diaminobenzidine chromogen (DAB, DAKO, Glostrup, Denmark). After incubation in chromogen, the slides were counterstained with haematoxylin, dehydrated, cleared in xylene, and mounted with a mounting medium. In every formed tumor, EZH2 and p53 positive cells were counted. In every tumor, two equal fields were randomly selected (size of the field $10000 \mu \mathrm{m}^{2}$ ). In every field, all cells were counted, positively stained cells and calculated percentage of EZH2 and p53 cells. Data were presented as \% of positively stained cells in every group.

2.6. Investigation of Tumor Invasion into Chorionic Epithelium and Mesenchyme. Serial histological sections of the experimental tumors and CAM were performed to evaluate tumor invasion. According to tumor behavior on the membrane they were distributed into three groups: (1) tumor was formed on the surface of the CAM, chorionic epithelium was not destroyed, and there was no invasion into the mesenchyme; (2) chorionic epithelium was destroyed and cells invaded the mesenchyme, but part of the tumor remained on the membrane surface; (3) tumor cells destroyed the chorionic epithelium, invaded the mesenchyme, and were completely surrounded by the mesenchyme.

2.7. Statistical Analysis. Data presented as mean and standard deviation. Data were compared using Tukey's test applying one-way ANOVA. Statistical package SPSS 20.0 was used. Difference was considered as significant when $p<0.05$. For visualization of the data, Sigma Plot 11.0 program was used. Data on cells positively stained for the EZH2 and p53 count were tested for normality distribution using two tests: the Kolmogorov-Smirnov and the Shapiro-Wilk (the Shapiro-Wilk test is more suitable for small-size samples). Both tests showed the normality of data distribution, and one-way ANOVA was applied for the data analysis.

\section{Results}

3.1. Biomicroscopy Data In Vivo. The U87 cells tumor xenografts inoculated on egg CAM and photographed daily via the shell window on days 9-12 of embryo development (EDD9-12) are shown in Figure 1. Figure 1(a) shows the development dynamics of nontreated U87 cell tumors during EDD9-12. In this group, the in vivo biomicroscopy highlighted the penetration of tumors into the underlying mesenchyme starting from day 2 after inoculation (at EDD9). Nontreated tumors are seen surrounded by formed new blood vessels and a clearly expressed spoked-wheel pattern which was observed on days 4 and 5 after grafting (Figure 1; EDD11-12). When cells were treated with $4 \mathrm{mM}$ of NaVP, they formed condensed tumors on CAM without invagination into the chorionic mesenchyme (Figure 1(b), EDD10-12). The tumors that developed from $8 \mathrm{mM}$ of NaVP-treated U87 cells did not show clear dynamics during 5 days of development: the in vivo biomicroscopy tumor images are very similar during days 2-5 (Figure 1(c), EDD9-12), and tumors failed to attract blood vessels. The $8 \mathrm{mM} \mathrm{NaVP}$-treated tumor cells were found distributed on CAM without penetrating the membrane. Such distribution of cells on the surface of CAM produces the misleading impression that the tumors have increased in size (Figures 1(c) and 2).

3.2. Histological Investigation of CAM with Implanted Tumors. Images of $\mathrm{H}$-E-stained slides of control CAM, the CAM with nontreated U87 cell tumors, and CAM with tumors of U87 cells treated with $4 \mathrm{mM}$ and $8 \mathrm{mM} \mathrm{NaVP}$ are presented in Figure 2. The control CAM is a thin membrane with the developed chorionic epithelium, allantoic epithelium, and a mesenchyme between these two epithelial layers and blood vessels (Figure 2(a)). The U87 cells form tumors on the CAM, which are related to the clearly thickened 

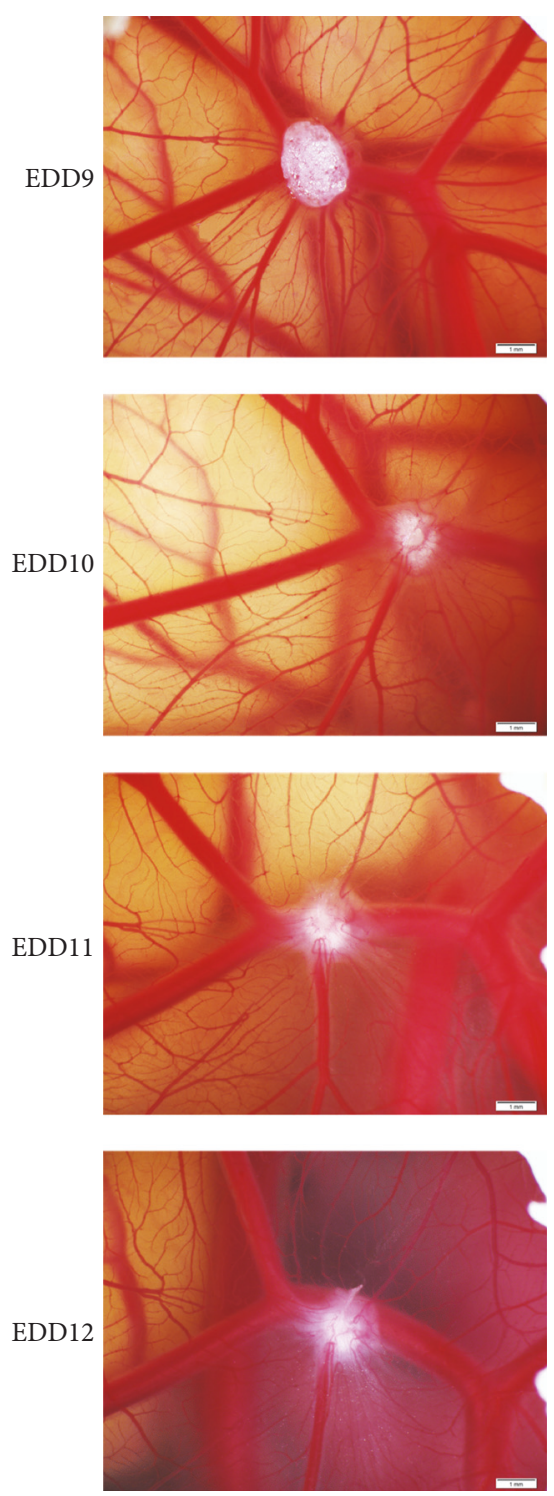

(a) Nontreated
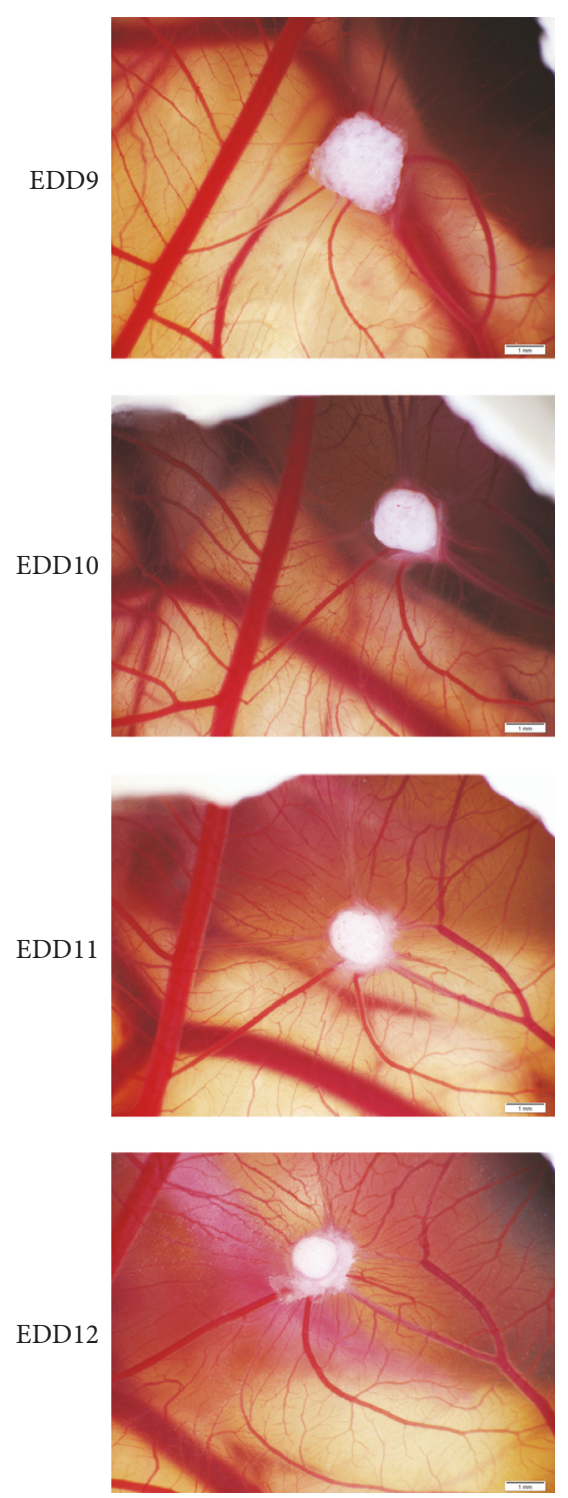

(b) NaVP-treated (4 mM)
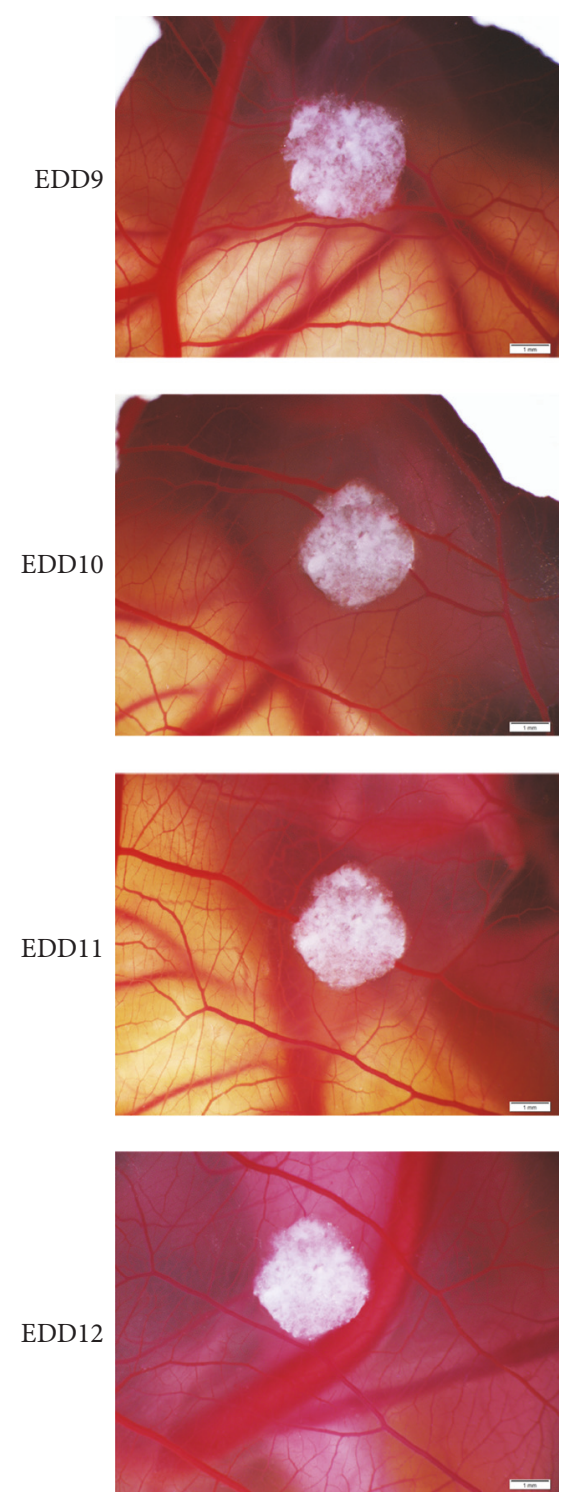

(c) NaVP-treated $(8 \mathrm{mM})$

FIGURE 1: Tumor xenograft on CAM of nontreated and NaVP-treated U87 cells during days 9-12 of embryo development. Figure 1 represents the U87 cell tumor xenografts on CAM growth dynamics, which was photographed daily on days 9-12 of embryo development (EDD9-12): (a) represents nontreated tumors, (b) NaVP-treated (with $4 \mathrm{mM}$ of NaVP) tumors, and (c) NaVP-treated (with $8 \mathrm{mM}$ of NaVP) tumors. The clearness of expression of nontreated tumor edges from the EDD10 gradually diminishes. This is related to tumor cell penetration into the mesenchyme since the EDD10 and with a clear and fast U87 cell invagination in the mesenchyme (a). Around nontreated tumors, the spokedwheel pattern is clearly expressed in the CAM on day EDD12 (a), while on the same day in the $4 \mathrm{mM}$ and $8 \mathrm{mM}$ NaVP-treated grafted tumors they failed to attract new blood vessels ((b) and (c), resp.). In the pictures of (c), the size of tumors treated with $8 \mathrm{mM}$ of NaVP in EDD9-12 is more pronounced as compared with tumors in (b), which is related to tumor cell penetration into the mesenchyme after treatment with $4 \mathrm{mM}$ of NaVP. In the pictures of (c), the spoked-wheel patterns are practically absent around the tumors. Scale bar: $1 \mathrm{~mm}$.

CAM mesenchyme under the onplant of nontreated tumors (Figures 2(b) and 2(c)) or the tumor is encapsulated in the thickened CAM mesenchyme (Figure 2(d)). The nontreated tumors are vascularized; blood vessels with chicken blood are clearly visible in them. The chorionic epithelium under the onplant is destroyed in most cases, and the invasion of glioblastoma cells into the CAM mesenchyme is obvious (Figures 2(b) and 2(c)). Tumors developed from U87 cells treated with $4 \mathrm{mM}$ and $8 \mathrm{mM}$ of $\mathrm{NaVP}$ are not vascularized, the chorionic epithelium is intact, glioblastoma cells are distributed on the CAM surface, and such distribution is more pronounced in tumors treated with $8 \mathrm{mM}$ of NaVP (Figures 2(e) and 2(f), resp.). The nontreated tumor causes mesenchyme hyperplasia which is reduced by the treatment with $\mathrm{NaVP}$, and this depends on the NaVP dose (Figure 2). 


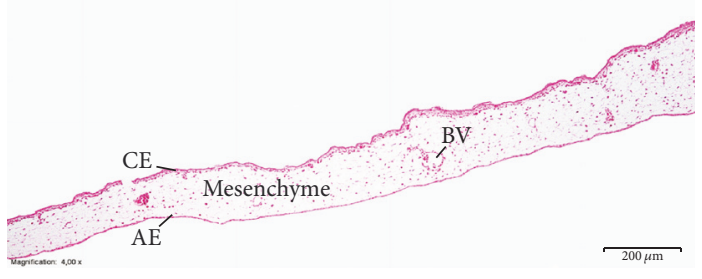

(a)

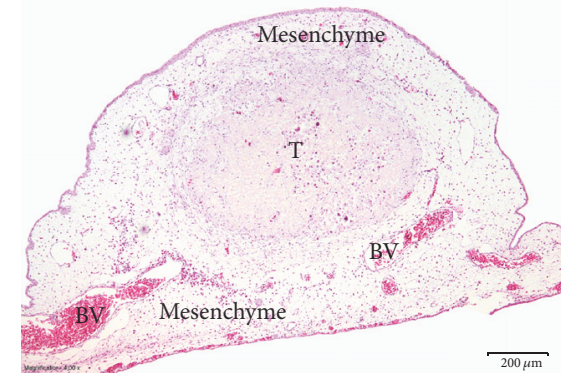

(d)

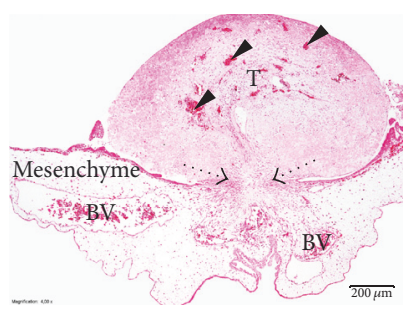

(b)

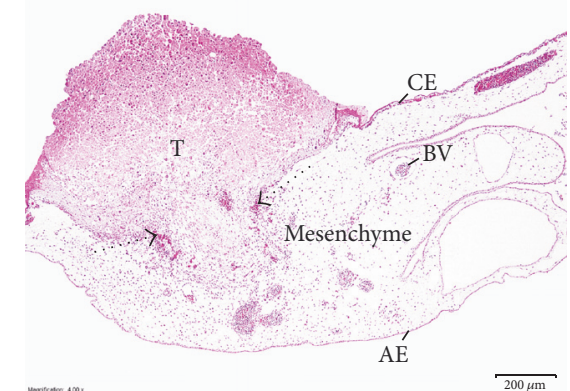

(c)

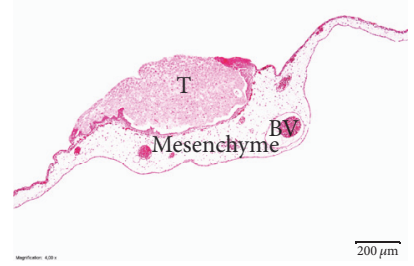

(e)

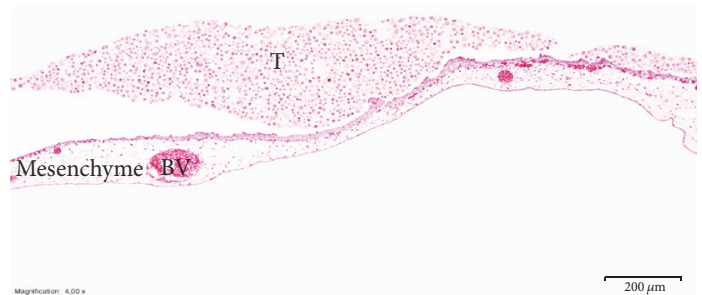

(f)

FIgURE 2: The CAM with U87 cell tumor at day 12 of embryo development. CE: chorionic epithelium, AE: allantoic epithelium, BV: blood vessels, and T: tumor. (a) Control membrane without tumor. (b) Membrane with tumor of U87 cells without treatment. Arrowheads show the growth of chicken blood vessels into the tumor, and a dotted arrow shows the chorionic epithelium destroyed by tumor cells. (c) Membrane with tumor developed from U87 cells treated with $4 \mathrm{mM} \mathrm{NaVP}$. The dotted arrow shows the destroyed chorionic epithelium and partial tumor invasion into the mesenchyme. (d) Membrane with a tumor developed from U87 cells without treatment. The tumor is completely encapsulated into the CAM mesenchyme. (e) Membrane with tumor developed from cells treated with $4 \mathrm{mM}$ of NaVP, with the intact chorionic epithelium; the tumor is not vascularized and located on the surface of the CAM. (f) Tumor developed from cells treated with $8 \mathrm{mM}$ of NaVP, located on the surface of the membrane, not vascularized. Scale bar: $200 \mu \mathrm{m}$.

3.3. Tumor Invasion into Chorionic Epithelium and Chorioallantoic Membrane Mesenchyme. Of the tumors developed from nontreated U87 cells, 50\% destroyed the chorionic epithelium, invaded the chorioallantoic membrane mesenchyme, and had been completely formed in the mesenchyme; $40 \%$ of the tumors destroyed the chorionic epithelium and invaded the mesenchyme but partly remained on the CAM surface, and only $10 \%$ of tumors were formed on the surface of the CAM without invading the mesenchyme. When U87 cells were treated with $4 \mathrm{mM}$ of NaVP, $60 \%$ of tumors were formed on the surface of the CAM and $30 \%$ destroyed the chorionic epithelium and invaded the mesenchyme, but part of the tumor remained on the surface of the CAM. In this group, $10 \%$ of tumors were observed only in the mesenchymal layer of the CAM. When U87 cells were treated with $8 \mathrm{mM}$ of NaVP, $90 \%$ of the tumors were formed on the surface of the CAM without invading the mesenchymal layer, the chorionic epithelium was also not destroyed, and only $10 \%$ of cases showed a complete invasion into the mesenchyme. Compared with nontreated tumors, the incidence of tumor formation on the CAM surface without invading the mesenchyme was significantly higher when U87 cells were treated with $4 \mathrm{mM}$ and $8 \mathrm{mM}$ of $\mathrm{NaVP}(10 \%$, $40 \%$, and $90 \%$, resp.; $p<0.05$ ). Comparing the incidence of the nontreated tumors and tumors whose U87 cells had been treated with $4 \mathrm{mM}$ and $8 \mathrm{mM}$ of $\mathrm{NaVP}$, tumors invading the CAM mesenchyme (the common group of tumors of which part invaded the mesenchyme and those localized only in the mesenchyme) were found significantly less frequently in the NaVP-treated tumor groups as compared with nontreated tumors $(10 \%, 40 \%$, and $90 \%$, resp.; $p<0.05)$. Tumors on the CAM were found more frequently in the $4 \mathrm{mM} \mathrm{NaVP}$ treated group as compared with the nontreated tumor group $(p<0.05)$, and comparing nontreated and the $4 \mathrm{mM} \mathrm{NaVP-}$ treated groups, the tumors which invaded the mesenchyme were significantly more frequent in the nontreated groups of tumor $(p<0.05$; Figure 3$)$.

\subsection{Immunohistochemical Investigation}

3.4.1. The EZH2 Protein Expression. In tumors formed by the U87 cells without treatment a high expression of the EZH2 protein was found, and positively stained cells were distributed in all tumor (Figure 4(a)). The EZH2 protein was expressed exclusively in the nuclei of the tumor cells. In tumors treated with $4 \mathrm{mM}$ of NaVP, cells with a positive staining for the EZH2 protein were located mostly in the upper part of a tumor (Figure 4(b)). In tumors treated with $8 \mathrm{mM}$ of NaVP, a weak staining for the EZH2 protein was observed (Figure 4(c)). The positive expression of the EZH2 


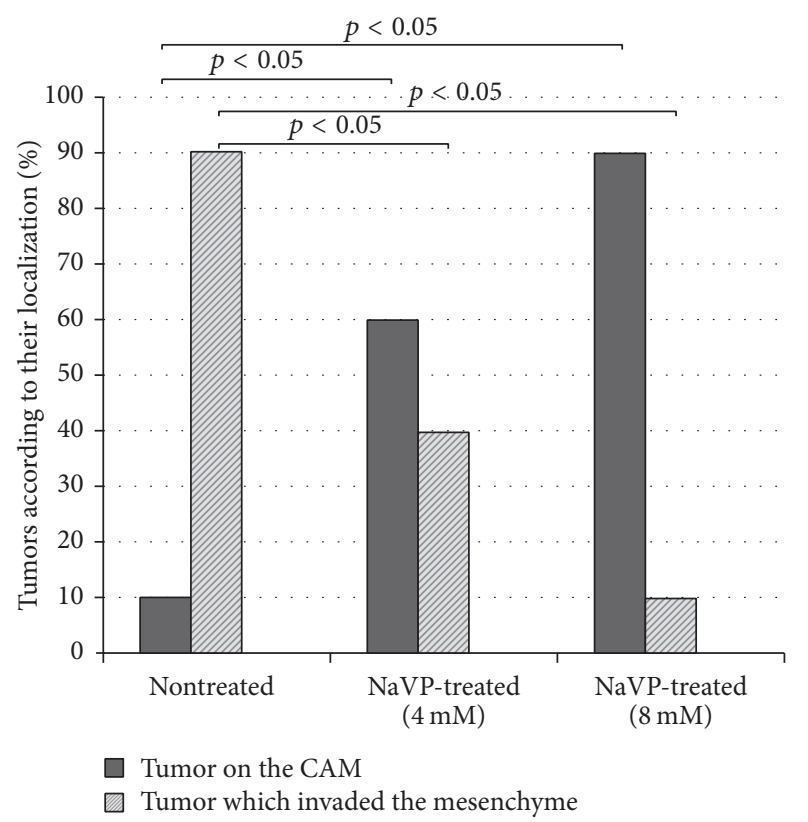

FIGURE 3: Frequency of U87 cell tumor groups with invasion into the CAM mesenchyme and localized only on the CAM. The investigated groups were U87 cell tumors nontreated with $\mathrm{NaVP}(n=10)$, treated with $4 \mathrm{mM}$ of $\mathrm{NaVP}(n=10)$, and treated with $8 \mathrm{mM}$ of $\mathrm{NaVP}(n$ $=10$ ). Tumors invading the CAM mesenchyme are presented as the common group containing tumors of which part of tumor invaded the mesenchyme and those localized only in the mesenchyme.

protein was observed also in the chorionic and allantoic epithelium and CAM mesenchyme in all investigated experimental groups. The EZH2-positive cell count in tumors formed by the nontreated U87 cells was $65 \pm 13 \%$ of all tumor cells. The EZH2-positive cells made $32 \pm 12 \%$ of all cells in tumors formed by cells treated with $4 \mathrm{mM}$ of NaVP. In tumors treated with $8 \mathrm{mM}$ of NaVP, only $6.3 \pm 5 \%$ of all tumor cells were positively stained for the EZH2 protein. The number of EZH2-positive cells was significantly lower in cells treated with $4 \mathrm{mM}$ and $8 \mathrm{mM}$ of NaVP as compared with the cell count in tumors formed by cells without treatment $(p<0.001$; Figure $4(\mathrm{~g})$ ), and the expression of the EZH2 protein was significantly higher in $4 \mathrm{mM} \mathrm{NaVP}$-treated group tumors as compared with the $8 \mathrm{mM}$ of NaVP-treated ones $(p<0.001$; Figure $4(\mathrm{~g}))$. Scale bar: $20 \mu \mathrm{m}$.

3.4.2. The p53 Protein Expression. In tumors formed by nontreated U87 cells, a high expression of the mutant p53 protein was found (Figure 4(d)). In tumors treated with $4 \mathrm{mM}$ of NaVP, the number of p53-positive cells diminished, and in tumors treated with $8 \mathrm{mM}$ of NaVP only a small number of positively stained cells were observed (Figures $4(\mathrm{e})$ and $4(\mathrm{f})$ ). The p53-positive cell count in tumors without treatment was $47.3 \pm 13 \%$ of all tumor cells. In tumors treated with $4 \mathrm{mM}$ of NaVP, the p53-positive cells made $18 \pm 8 \%$ of all cells, and in tumors treated with $8 \mathrm{mM}$ of NaVP only $6.4 \pm 5 \%$ of all tumor cells were positively stained for the p53 protein. The number of p53-positive cells was significantly lower in cells treated with $4 \mathrm{mM}$ and $8 \mathrm{mM}$ of NaVP as compared with the cell count of nontreated tumors $(p<0.001)$, and treatment with $8 \mathrm{mM}$ of NaVP significantly diminished the expression of p53 as compared with $4 \mathrm{mM}$ of NaVP-treated tumors ( $p<$ 0.007; Figure 4(h)). Scale bar: $20 \mu \mathrm{m}$.

\section{Discussion}

GBM is the most lethal form of cancer with a median survival of up to 12 months [1]. Seizures occur in up to $90 \%$ of patients with low-grade gliomas and in up to $60 \%$ with highgrade gliomas [41, 42]. Tumor growth stimulates seizures, and seizures activate tumor growth [43]. The antiepileptic drug NaVP has the promising anticancer effects: it stimulates histone acetylation, leading to an unfolding of the chromatin structure that leaves DNA more susceptible to the effects of chemotherapy and radiation therapy [44]. In vitro and in vivo combined $\mathrm{NaVP}$ and temozolomide treatment induces apoptosis and autophagy of cancer cells $[45,46]$. The EORTC trial of temozolomide and chemoradiation showed that the median survival of glioblastoma patients who received $\mathrm{NaVP}$ was significantly longer than of patients treated by chemoradiation alone [47, 48].

In vivo experimental studies demonstrate that the CAM model allows a successful testing of investigational medicinal products. The CAM model has been used to implant several malignant cell lines to investigate tumor growth and the metastatic process, angiogenic potential, identifying therapeutic targets, and evaluating antitumor drugs, as these transplanted cells on CAM keep producing human antigens $[33,34,49]$. CAM is formed on days 4 to 5 of embryo development. The CAM is a thin, highly vascularized membrane located beneath the egg shell and consisting of the chorionic epithelium, mesenchyme, and allantoic epithelium [36]. A chick embryo until day 18 of EDD may serve as a naturally immunodeficient host for the investigation of transplanted cells $[38,50]$. Investigators suggest that experimental glioma growth on the CAM exhibits a sufficient similarity with fundamental aspects of the human disease: defined tumor growth with key features of human glioblastoma at cellular and molecular levels occurs in a reproducible manner after human GBM cell grafting [51]. GBM is characterized by a fast cell proliferation, infiltrative migration, and the angiogenesis induction [20,52].

The study biomicroscopy follow-up of control-nontreated and NaVP-treated U87 cell tumors on CAM shows a progressive growth and vascularization. The majority of tumors which developed from U87 cells without NaVP treatment during tumor growth destroyed the chorionic epithelium and invaded the mesenchyme. Biomicroscopy showed that the nontreated xenograft of U87 cells on CAM invaginated into the underlying mesenchyme starting from day 2 after inoculation. The study shows that increasing the NaVP concentration diminished the U87 cell capability to destroy the chorionic epithelium and significantly increased the number of tumors formed only on the surface of the CAM without invading the mesenchyme. The incidence of tumor formation on CAM without invasion into the mesenchyme was significantly higher when U87 cells have been treated 


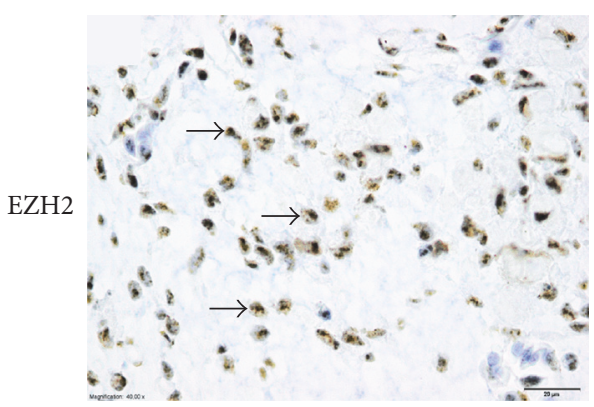

(a)

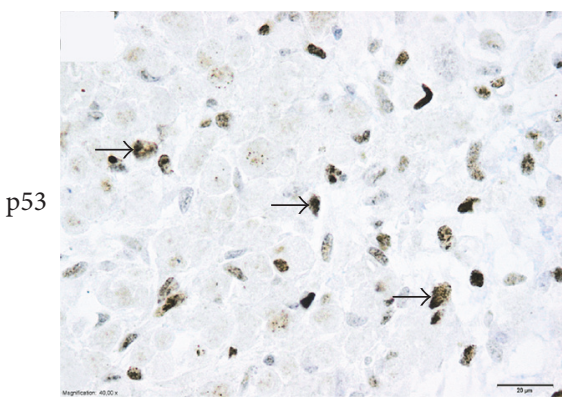

(d)

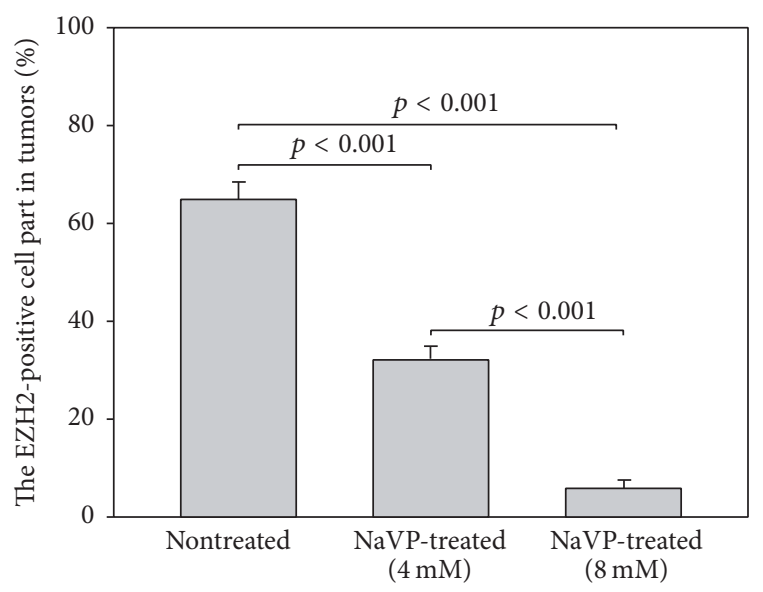

(g)

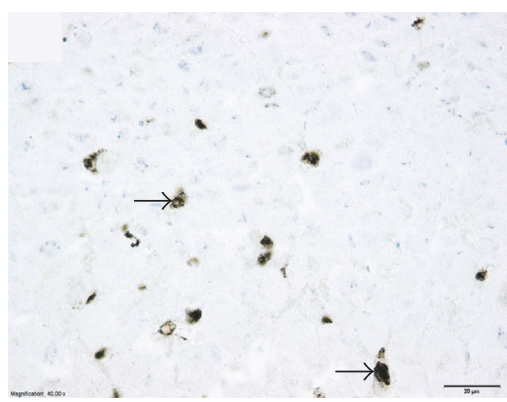

(b)

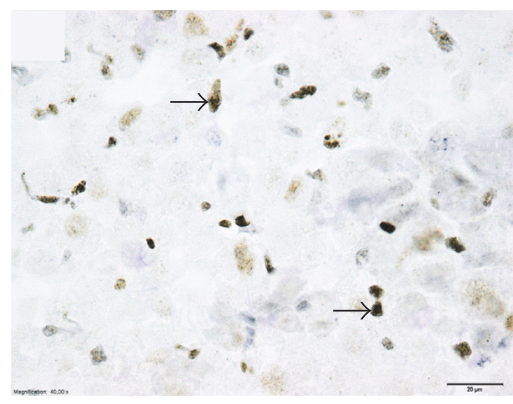

(e)

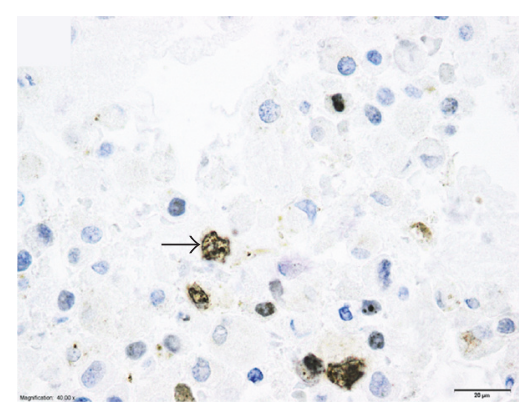

(c)

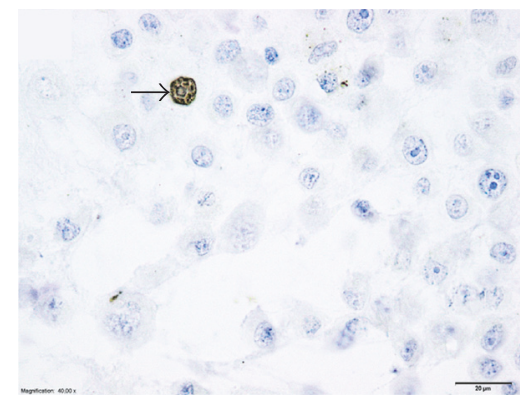

(f)

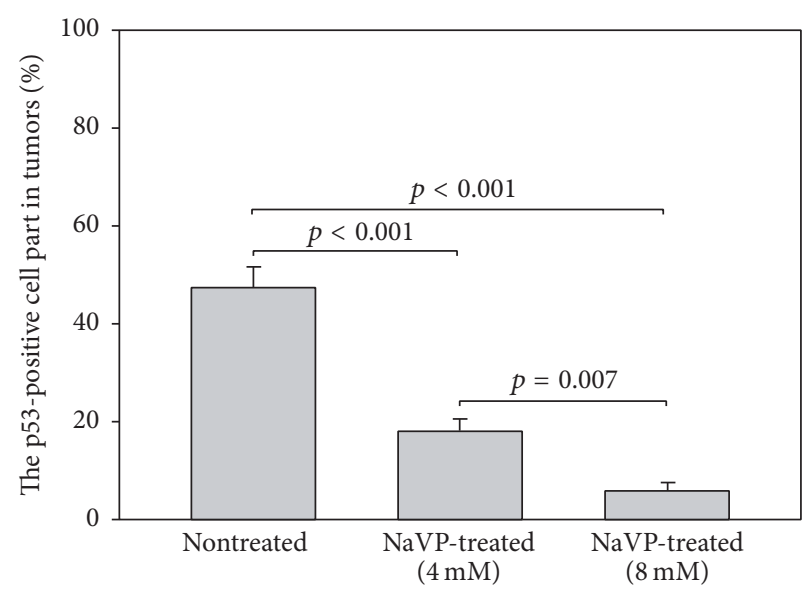

(h)

FIGURE 4: Expression of EZH2 and p53 proteins in tumors formed by U87 cells treated with $4 \mathrm{mM}$ and $8 \mathrm{mM}$ of NaVP and by nontreated cells. (a) EZH2 expression in nontreated tumors, (b) EZH2 expression in tumors treated with $4 \mathrm{mM}$ of NaVP, (c) EZH2 protein expression in tumors treated with $8 \mathrm{mM}$ of NaVP. (d) p53 protein expression in tumors formed by nontreated U87 cells, (e) p53 expression in tumors treated with $4 \mathrm{mM}$ of NaVP, and (f) p53 protein expression in tumors treated with $8 \mathrm{mM}$ of NaVP. (g) EZH2-positive cells and (h) p53-positive cell tumors developed from U87 cells in tumor groups without treatment and from cells treated with $4 \mathrm{mM}$ and $8 \mathrm{mM}$ of NaVP, respectively. Arrows indicate EZH2- and p53-positive cells.

with $\mathrm{NaVP}$, and this effect significantly increased with the NaVP concentration. NaVP is a histone-deacetylase (HDCE) inhibitor and specifically inhibits HDAC classes I and IIa [53]. NaVP is able to induce apoptosis in glioma U87 cells in a dose-dependent manner [16], and the U87 cells may be more sensitive to NaVP than the other GBM lines [8]. Other researchers investigation of NaVP effects on tumor cells in vitro demonstrated that it inhibited cell proliferation by causing cell cycle arrest in the G1 and/or G2 phase and that it induced differentiation and/or apoptosis in various cancer cells $[54,55]$, reduced the proliferation of glioblastomaderived stem cells [56], and decreased the viability of primary human glioblastoma cells [57].

The U87 tumors on CAM in relationship with tumor progression concomitantly induced blood vessel angiogenesis, and a clearly expressed spoked-wheel pattern was observed on days 4 and 5 after grafting in nontreated tumors. The treatment of U87 cells with $8 \mathrm{mM}$ of NaVP did not show clear 
dynamics of tumor growth during 5 days of development at EDD9-12; at the same time, the blood vessel angiogenesis failed. Other researchers reported that the progression of the U78 tumor was related to angiogenesis which indicates a glioma development relationship with growth factor receptors [58], and platelet-derived growth factor receptors [59] are important for angiogenesis and glioma progression, and their inhibition could result in the inhibition of experimental glioma growth [51].

The studied GBM U87 cell tumor samples showed a strong nuclear staining of EZH2 in U87 cell tumors without $\mathrm{NaVP}$ treatment, and a high expression of the $\mathrm{EZH} 2$ protein in the tumor cell nuclei was found. It is known that increased EZH2 expression correlates with glioma grade and its recurrence, suggesting that $\mathrm{EZH} 2$ could be a marker of glioma aggressiveness and correlate with a decreased GBM patient survival, and the EZH2 protein was found to be strongly expressed in U87 cell lines. EZH2 is present only in dividing cells [20].

In our study, the expression of EZH2 protein was observed also in the chorionic and allantoic epithelium and CAM mesenchyme in nontreated with NaVP tumors. This positive staining may be associated with the fact that the EZH2 protein participates in embryo development: the $\mathrm{EZH} 2$ knockdown was shown to be embryo-lethal in mice [21]; the knockdown of EZH2 in cancer cells resulted in diminished tumor growth and reduced metastases in vivo $[53,60,61]$. EZH2 in glioblastoma leads to cell cycle arrest at the $G_{0} / G_{1}$ phase, further leading to the uncontrolled cell cycle progression in glioblastoma cells [19]. EZH2 is actively involved in cell cycle progression, cell proliferation, cell differentiation, and apoptosis [62]. EZH2 promotes the epithelial to mesenchymal transition program which is a known mechanism inducing tumor aggressiveness and metastases $[22,23]$.

We found that the number of EZH2-positive cells was significantly lower in tumors treated with $4 \mathrm{mM}$ and $8 \mathrm{mM}$ of $\mathrm{NaVP}$ as compared with the cell count in nontreated tumors, and the NaVP effect was higher as its concentration increased to $8 \mathrm{mM}$. It was reported that the inhibition of EZH2 may be a potential therapeutic strategy to target GBM proliferation, migration, and angiogenesis as the inhibition of EZH2 in vitro by pre-miR-101, EZH2 siRNA, or small molecule DZNep attenuated GBM cell growth, migration/invasion, and GBM-induced endothelial tubule formation in a U87-Fluc-mCherry GBM xenograft mouse imaging model resulted in a reduced tumor growth and migration/invasion. A significant correlation between the expression of 28 out of 279 genes associated with cell migration and EZH2 expression was observed [20]. The effectiveness of NaVP on EZH2 in U87 tumors indicates that NaVP has a potential therapeutic strategy to target GBM proliferation, invasiveness, and differentiation. Furthermore, several studies have reported that EZH2 inhibition increases the sensitivity of different cancer cells to radiation and chemotherapy [63-65]. The inhibition of EZH2 in B cell lymphomas induces p53-mediated apoptosis under DNA damage accumulation, resensitizing lymphomas cells to chemotherapy [66].
In the nontreated U87 cell tumors, the EZH2 expression in cells has been very strongly expressed in tumor areas which invaded across the chorionic membrane to the mesenchyme and were surrounded by the thickened mesenchyme. In this respect, of significance could be the results of other studies indicating that tumor infiltrating front, molecular heterogeneity in GBM can improve the rationale of potential molecular targets. The key genes involved in gliomas tumor cell proliferation, invasion, migration, response to immune system, and stemness markers are highly enriched in the peritumoral brain zone, and these genes probably contribute to the resistance of cells to standard therapy, resulting in a tumor recurrence [67].

The study shows that, in tumors formed by the U87 cells without NaVP treatment, a high expression of the $\mathrm{p} 53$ protein was found. The p53 is a tumor suppressor gene implicated in the genesis of malignancies. The overexpression of the p53 protein is often used as a surrogate indicator of mutations in the p53 gene [68]. The role of p53 in glioma progression is under ongoing discussion, because the overexpression of mutated p53 may mark the biology of a higher tumor progression [30]. The p53 protein is a transcription factor important in tumor growth, cell apoptosis $[69,70]$, activating the cell cycle [70], differentiation [71], and being involved in DNA repair [72]. The p53 gene encodes a 393-amino acid protein; p53 is a phosphoprotein that resides in the nucleus. The p53 gene mutations are one of the distinct features seen in GBM [73]. The nuclear overexpression of p53 in secondary GBM reflects the presence of mutant $\mathrm{p} 53$, and these mutations are involved in GBM progression [74]. However, the incidence of p53 protein accumulation in glioma is more frequently seen than p53 mutations [75-77] and the percentage of glioma cells, in which p53 protein accumulation is found to increase from the first biopsy to recurrent tumors [76]. Furthermore, p53 expression in GBM may accumulate in the cytoplasm. The role of p53 in cytoplasmic location is not clear. Some researchers indicate that it could be inactive $[30,75]$. The expression of p53 in the human glioma U87 cell line nuclei was found to depend on the used animal model: the percentage of human glioblastoma p53-positive nuclei of the same xenograft was higher in the tumors grown on the chick chorioallantoic membrane than in the brain of a nude rat model [33]. Furthermore, the historical focus on p53 in the nucleus is broadened with its localization in mitochondria [78].

The p53 abnormalities are common in the progression from a low-grade lesion to a high-grade lesion of GBM in patients $[73,79]$, and the association between p53 mutations and GBM progression remains unclear [30]. The status of p53 had a little effect on the survival of GBM patients $[74,80]$. Some reported that $\mathrm{p} 53$ expression was more common in the long-term survival irrespective of the specific types of p53 mutation [32], while others, on the contrary, indicated that patients who did not have immunohistochemical expression of p53 had a significantly longer median survival time than those with its positive expression [31]. No relation of the p53 status and time with tumor progression was found [81]. Several studies have indicated that p53 was significantly altered in patients with malignant transformation rather than 
in those with no apparent progression [82, 83]. Also, wt p53 failed to sensitize glioma cells to cytotoxic drugs and, therefore, contributed to chemoresistance [84].

Our study revealed a high expression of p53 in U87 cell tumors which were not treated with NaVP, and this expression was accompanied with pronounced angiogenesis in tumors in the CAM model. The p53 distribution in the tumor was not related to tumor periphery or vascularization areas. Other investigators also found that the pattern of p53 expression was not related to a particular region, such as the infiltrating edges or vascularization areas in GBM of patients [85]. Others reported that the cytoplasmic p53 expression was exclusively seen in the perivascular areas in $57 \%$ of de novo cases of GBM, and the expression of cytoplasmic p53 around the perivascular area may represent its role in angiogenesis [30]. Immunoreactivity of the vascular endothelial growth factor (VEGF) in GBM cells was associated with vascularity and positively correlated with p53 expression, suggesting an association between mutant p53 and VEGF [86].

In our U78 tumors on CAM treated with NaVP, the number of p53-positive cells significantly diminished, and only a significantly decreased number of p53-positive cells in tumors treated with $8 \mathrm{mM}$ of $\mathrm{NaVP}$ were observed. By others, the mechanistic insight shows that p53 directly interacts with the antiapoptotic proteins bcl-xL and bcl-2, and mutant $\mathrm{p} 53$ proteins could be related to this binding [87]. It was reported that NaVP induced by p53-dependent mitochondrial localization of Bax and Bcl-xL, as well as the mitochondrial membrane potential and cytochrome $c$ release, are important for the p53 role in NaVP-mediated radiosensitization of cancer cells [88].

\section{Conclusion}

The study results demonstrate that the CAM model allows a successful testing of anticancer drugs designed to interfere with the p53 and EZH2 molecular pathways important for glioma progression. The experimental findings of the study indicate that NaVP has a function in blocking the proliferation, migration, and angiogenesis of human U87 glioma cells in the CAM tumor model, thereby supporting the $\mathrm{NaVP}$ potential in glioblastoma therapy. However, the U87 cell model system used in the study has limitations due to the known high cell line mutability and variability, but the study results are important for further studies to evaluate the NaVP effect on the p53 and EZH2 expression of different (pediatric and adult) cell and brain tumor stem cell lines as well as the primary GMB tumor cell cultures.

\section{Conflicts of Interest}

The authors declare no conflicts of interests.

\section{Acknowledgments}

The present study was supported by the Lithuanian University of Health Science (Grant no. V-1238).

\section{References}

[1] K. R. Hess, K. R. Broglio, and M. L. Bondy, "Adult glioma incidence trends in the United States, 1977-2000," Cancer, vol. 101, no. 10, pp. 2293-2299, 2004.

[2] M. S. van Breemen, R. M. Rijsman, M. J. Taphoorn, R. Walchenbach, H. Zwinkels, and C. J. Vecht, "Efficacy of antiepileptic drugs in patients with gliomas and seizures," Journal of Neurology, vol. 256, no. 9, pp. 1519-1526, 2009.

[3] M. S. Van Breemen, E. B. Wilms, and C. J. Vecht, "Epilepsy in patients with brain tumours: epidemiology, mechanisms, and management," The Lancet Neurology, vol. 6, no. 5, pp. 421-430, 2007.

[4] G. Rosenberg, "The mechanisms of action of valproate in neuropsychiatric disorders: can we see the forest for the trees?" Cellular and Molecular Life Sciences, vol. 64, no. 16, pp. 2090 2103, 2007.

[5] E. Spina and G. Perugi, "Antiepileptic drugs: indications other than epilepsy," Epileptic Disorders, vol. 6, no. 2, pp. 57-75, 2004.

[6] P. Y. Wen and D. Schiff, "Valproic acid as the AED of choice for patients with glioblastoma? The jury is out," Neurology, vol. 77, no. 12, pp. 1114-1115, 2011.

[7] Y. Yang, X. Wang, Q. Mao, Y. Liu, J. Luo, and Y. Mao, "Survival analysis for valproic acid use in adult glioblastoma multiforme: a meta-analysis of individual patient data and a systematic review," Seizure, vol. 23, no. 10, pp. 830-835, 2014.

[8] C. H. Ryu, W. S. Yoon, K. Y. Park et al., "Valproic acid downregulates the expression of MGMT and sensitizes temozolomideresistant glioma cells," Journal of Biomedicine \& Biotechnology, vol. 2012, Article ID 987495, 9 pages, 2012.

[9] Y. Ghodke-Puranik, C. F. Thorn, J. K. Lamba et al., "Valproic acid pathway: pharmacokinetics and pharmacodynamics," Pharmacogenetics and Genomics, vol. 23, no. 4, pp. 236-241, 2013.

[10] S. Berendsen, M. Broekman, T. Seute et al., "Valproic acid for the treatment of malignant gliomas: review of the preclinical rationale and published clinical results," Expert Opinion on Investigational Drugs, vol. 21, no. 9, pp. 1391-1415, 2012.

[11] A. Chavez-Blanco, C. Perez-Plasencia, E. Perez-Cardenas et al., "Antineoplastic effects of the DNA methylation inhibitor hydralazine and the histone deacetylase inhibitor valproic acid in cancer cell lines," Cancer Cell International, vol. 6, article 2, 2006.

[12] M. Michaelis, T. Suhan, J. Cinatl, P. H. Driever, and J. Cinatl Jr., "Valproic acid and interferon-alpha synergistically inhibit neuroblastoma cell growth in vitro and in vivo," International Journal of Oncology, vol. 25, no. 6, pp. 1795-1799, 2004.

[13] R. A. Blaheta, M. Michaelis, I. Natsheh et al., "Valproic acid inhibits adhesion of vincristine- and cisplatin-resistant neuroblastoma tumour cells to endothelium," British Journal of Cancer, vol. 96, no. 11, pp. 1699-1706, 2007.

[14] J. Grikiniene, D. Stakisaitis, and M. Tschaika, "Influence of sodium valproate on sodium and chloride urinary excretion in rats, gender differences," Pharmacology, vol. 75, no. 3, pp. 111115, 2005.

[15] D. Thotala, R. M. Karvas, J. A. Engelbach et al., "Valproic acid enhances the efficacy of radiation therapy by protecting normal hippocampal neurons and sensitizing malignant glioblastoma cells," Oncotarget, vol. 6, pp. 35004-35022, 2015.

[16] C. Zhang, S. Liu, X. Yuan et al., "Valproic acid promotes human glioma U87 cells apoptosis and inhibits glycogen synthase 
kinase- $3 \beta$ through ERK/Akt signaling," Cellular Physiology and Biochemistry, vol. 39, no. 6, pp. 2173-2185, 2016.

[17] A. Christofides, T. Karantanos, K. Bardhan, and V. A. Boussiotis, "Epigenetic regulation of cancer biology and anti-tumor immunity by EZH2," Oncotarget, vol. 7, pp. 85624-85640, 2016.

[18] K. H. Kim and C. W. M. Roberts, "Targeting EZH2 in cancer," Nature Medicine, vol. 22, no. 2, pp. 128-134, 2016.

[19] J. Zhang, L. Chen, L. Han, Z. Shi, P. Pu, and C. Kang, "EZH2 is a negative prognostic factor and exhibits prooncogenic activity in glioblastoma," Cancer Letters. Part B, vol. 356, no. 2, pp. 929936, 2015.

[20] M. Smits, J. Nilsson, S. E. Mir et al., "miR-101 is downregulated in glioblastoma resulting in EZH2-induced proliferation, migration, and angiogenesis," Oncotarget, vol. 1, no. 8, pp. 710-720, 2010.

[21] D. O'Carroll, S. Erhardt, M. Pagani, S. C. Barton, M. A. Surani, and T. Jenuwein, "The polycomb-group gene Ezh2 is required for early mouse development," Molecular and Cellular Biology, vol. 21, no. 13, pp. 4330-4336, 2001.

[22] D. N. Ma, Z. T. Chai, X. D. Zhu et al., "MicroRNA-26a suppresses epithelial-mesenchymal transition in human hepatocellular carcinoma by repressing enhancer of zeste homolog 2," Journal of Hematology \& Oncology, vol. 9, article 1, 2016.

[23] Q. Cao, J. Yu, SM. Dhanasekaran et al., "Repression of Ecadherin by the polycomb group protein EZH2 in cancer," Oncogene, vol. 27, no. 58, pp. 7274-7284, 2008.

[24] K. C. Sia, H. Huynh, A. Y. Chung et al., "Preclinical evaluation of transcriptional targeting strategy for human hepatocellular carcinoma in an orthotopic xenograft mouse model," Molecular Cancer Therapeutics, vol. 12, no. 8, pp. 1651-1664, 2013.

[25] M. Sha, G. Mao, G. Wang, Y. Chen, X. Wu, and Z. Wang, "DZNep inhibits the proliferation of colon cancer HCT116 cells by inducing senescence and apoptosis," Acta Pharmaceutica Sinica B, vol. 5, no. 3, pp. 188-193, 2015.

[26] K. Bieging, S. Mello, and L. Attardi, "Unravelling mechanisms of p53-mediated tumour suppression," Nature Review Cancer, vol. 14, no. 5, pp. 359-370, 2014.

[27] K. H. Vousden and C. Prives, "Blinded by the light: the growing complexity of p53," Cell, vol. 137, no. 3, pp. 413-431, 2009.

[28] H. Zheng, H. Ying, H. Yan et al., "p53 and Pten control neural and glioma stem/progenitor cell renewal and differentiation," Nature, vol. 455, no. 7216, pp. 1129-1133, 2008.

[29] D. Biasoli, M. F. Sobrinho, A. C. C. da Fonseca et al., "Glioblastoma cells inhibit astrocytic p53-expression favoring cancer malignancy," Oncogenesis, vol. 3, article e123, 2014.

[30] J. Nagpal, A. Jamoona, N. D. Gulati et al., "Revisiting the role of p53 in primary and secondary glioblastomas," Anticancer Research, vol. 26, no. 6C, pp. 4633-4640, 2006.

[31] K. G. Abdullah, A. Ramayya, J. P. Thawani et al., "Factors associated with increased survival after surgical resection of glioblastoma in octogenarians," PLoS ONE, vol. 10, no. 5, Article ID e0127202, 2015.

[32] E. C. Burton, K. R. Lamborn, P. Forsyth et al., "Aberrant p53, $\mathrm{mdm} 2$, and proliferation differ in glioblastomas from longterm compared with typical survivors," Clinical Cancer Research, vol. 8, no. 1, pp. 180-187, 2002.

[33] T. Strojnik, R. Kavalar, T. A. Barone, and R. J. Plunkett, “Experimental model and immunohistochemical comparison of U87 human glioblastoma cell xenografts on the chicken chorioallantoic membrane and in rat brains," Anticancer Research, vol. 30, no. 12, pp. 4851-4860, 2010.
[34] R. Stupp, W. P. Mason, M. J. van den Bent et al., "Radiotherapy plus concomitant and adjuvant temozolomide for glioblastoma," The New England Journal of Medicine, vol. 352, no. 10, pp. 987-996, 2005.

[35] M. Liu, C. S. Scanlon, R. Banerjee et al., "The histone methyltransferase EZH2 mediates tumor progression on the chick chorioallantoic membrane assay, a novel model of head and neck squamous cell carcinoma," Translational Oncology, vol. 6, no. 3, pp. 273-281, 2013.

[36] D. Ribatti, "The chick embryo chorioallantoic membrane as an in vivo assay to study antiangiogenesis," Pharmaceuticals, vol. 3, no. 3, pp. 482-513, 2010.

[37] A. Vargas, M. Zeisser-Labouèbe, N. Lange, R. Gurny, and F. Delie, "The chick embryo and its chorioallantoic membrane (CAM) for the in vivo evaluation of drug delivery systems," Advanced Drug Delivery Reviews, vol. 59, no. 11, pp. 1162-1176, 2007.

[38] E. I. Deryugina and J. P. Quigley, "Chick embryo chorioallantoic membrane model systems to study and visualize human tumor cell metastasis," Histochemistry and Cell Biology, vol. 130, no. 6, pp. 1119-1130, 2008.

[39] D. Ribatti, The Chick Embryo Chorioallantoic Membrane in the Study of Angiogenesis and Metastasis, Springer Science+Business Media B.V, London, UK, 2010.

[40] N. Balciuniene, A. Tamasauskas, A. Valanciute et al., "Histology of human glioblastoma transplanted on chicken chorioallantoic membrane," Medicina, vol. 45, no. 2, pp. 123-131, 2009.

[41] M. Kerkhof and C. J. Vecht, "Seizure characteristics and prognostic factors of gliomas," Epilepsia, vol. 54, supplement 9, pp. 12-17, 2013.

[42] A. A. Lane and B. A. Chabner, "Histone deacetylase inhibitors in cancer therapy," Journal of Clinical Oncology, vol. 27, no. 32, pp. 5459-5468, 2009.

[43] H. S. Venkatesh, T. B. Johung, V. Caretti et al., "Neuronal activity promotes glioma growth through neuroligin-3 secretion," Cell, vol. 161, no. 4, pp. 803-816, 2015.

[44] Š. Cipro, J. Hřebačková, J. Hraběta, J. Poljaková, and T. Eckschlager, "Valproic acid overcomes hypoxiainduced resistance to apoptosis," Oncology Reports, vol. 27, no. 4, pp. 12191226, 2012.

[45] K. A. van Nifterik, J. Van den, B. J. Berg, M. V. Lafleur, P. Sminia, and L. J. Stalpers, "Valproic acid sensitizes human glioma cells for temozolomide and $\gamma$-radiation," Journal of Neuro-Oncology, vol. 107, no. 1, pp. 61-67, 2012.

[46] C. H. Chen, Y. J. Chang, M. S. Ku, K. T. Chung, and J. T. Yang, "Enhancement of temozolomide-induced apoptosis by valproic acid in human glioma cell lines through redox regulation," Journal of Molecular Medicine, vol. 89, no. 3, pp. 303-315, 2011.

[47] M. Weller, T. Gorlia, J. G. Cairncross et al., "Prolonged survival with valproic acid use in the EORTC/NCIC temozolomide trial for glioblastoma," Neurology, vol. 77, no. 12, pp. 1156-1164, 2011.

[48] M. Kerkhof, J. C. Dielemans, M. S. van Breemen et al., "Effect of valproic acid on seizure control and on survival in patients with glioblastoma multiforme," Neuro-Oncology, vol. 15, no. 7, pp. 961-967, 2013.

[49] D. Ribatti, "The chick embryo chorioallantoic membrane as a model for tumor biology," Experimental Cell Research, vol. 328, no. 2, pp. 314-324, 2014.

[50] V. Uloza, A. Kuzminiene, J. Palubinskiene, I. Balnyte, I. Ulozienè, and A. Valančiūte, "Model of human recurrent respiratory papilloma on chicken embryo chorioallantoic membrane 
for tumor angiogenesis research," Histology and Histopathology, vol. 32, no. 7, pp. 699-710, 2017.

[51] M. Hagedorn, S. Javerzat, D. Gilges et al., "Accessing key steps of human tumor progression in vivo by using an avian embryo model," Proceedings of the National Academy of Sciences of the United States of America, vol. 102, no. 5, pp. 1643-1648, 2005.

[52] E. C. Holland, "Glioblastoma multiforme: the terminator," Proceedings of the National Academy of Sciences of the United States of America, vol. 97, no. 12, pp. 6242-6244, 2000.

[53] O. H. Krämer, P. Zhu, H. P. Ostendorff et al., "The histone deacetylase inhibitor valproic acid selectively induces proteasomal degradation of HDAC2," The EMBO Journal, vol. 22, no. 13, pp. 3411-3420, 2003.

[54] M. Gottlicher, S. Minucci, P. Zhu et al., "Valproic acid defines a novel class of HDAC inhibitors inducing differentiation of transformed cells," The EMBO Journal, vol. 20, no. 24, pp. 69696978, 2001.

[55] P. Marks, R. A. Rifkind, V. M. Richon, R. Breslow, T. Miller, and W. K. Kelly, "Histone deacetylases and cancer: causes and therapies," Nature Reviews. Cancer, vol. 1, no. 3, pp. 194-202, 2001.

[56] A. A. Alvarez, M. Field, S. Bushnev, M. S. Longo, and K. Sugaya, "The effects of histone deacetylase inhibitors on glioblastomaderived stem cells," Journal of Molecularneurosciens, vol. 55, no. 1, pp. 7-20, 2015.

[57] A. N. Hosein, Y. C. Lim, B. Day et al., "The effect of valproic acid in combination with irradiation and temozolomide on primary human glioblastoma cells," Journal of Neuro-Oncology, vol. 122, no. 2, pp. 263-271, 2015.

[58] B. Millauer, L. K. Shawver, K. H. Plate, W. Risau, and A. Ullrich, "Glioblastoma growth inhibited in vivo by a dominant-negative Flk-1 mutant," Nature, vol. 367, no. 6463, pp. 576-579, 1994.

[59] L. M. Strawn, E. Mann, S. S. Elliger et al., "Inhibition of glioma cell growth by a truncated platelet-derived growth factor-beta receptor," The Journal of Biological Chemistry, vol. 269, no. 33, pp. 21215-21222, 1994.

[60] F. Takeshita, Y. Minakuchi, S. Nagahara et al., "Efficient delivery of small interfering RNA to bone-metastatic tumors by using atelocollagen in vivo," Proceedings of the National Academy of Sciences of the United States of America, vol. 102, no. 34, pp. 12177-12182, 2005.

[61] J. Yu, Q. Cao, R. Mehra et al., "Integrative genomics analysis reveals silencing of beta-adrenergic signaling by polycomb in prostate cancer," Cancer Cell, vol. 12, no. 5, pp. 419-431, 2007.

[62] K. H. Kim and C. W. Roberts, "Targeting EZH2 in cancer," Nature Medicine, vol. 22, no. 2, pp. 128-134, 2016.

[63] I. Alimova, D. K. Birks, P. S. Harris et al., "Inhibition of EZH2 suppresses self-renewal and induces radiation sensitivity in atypical rhabdoid teratoid tumor cells," Neuro-Oncology, vol. 15, no. 2, pp. 149-160, 2013.

[64] H. Xia, C. H. Yu, Y. Zhang et al., "EZH2 silencing with RNAi enhances irradiation-induced inhibition of human lung cancer growth in vitro and in vivo," Oncology Letters, vol. 4, no. 1, pp. 135-140, 2012.

[65] C. M. Fillmore, C. Xu, P. T. Desai et al., "EZH2 inhibition sensitizes BRG1 and EGFR mutant lung tumours to TopoII inhibitors," Nature, vol. 520, no. 7546, pp. 239-242, 2015.

[66] M. Smonskey, E. Lasorsa, S. Rosario, J. S. Kirk, F. J. HernandezIlizaliturri, and L. Ellis, "EZH2 inhibition re-sensitizes multidrug resistant B-cell lymphomas to etoposide mediated apoptosis," Oncoscience, vol. 3, no. 1, pp. 21-30, 2016.
[67] A. Arimappamagan, R. Kruthika, K. Paturu, and V. Santosh, "332 Molecular characteristics of tumor infiltrating front in glioblastoma: insights into molecular heterogeneity and implications on targeted therapy," Neurosurgery, vol. 63, supplement 1, p. 197, 2016.

[68] A. Nayak, A. M. Ralte, M. C. Sharma et al., "p53 Protein alterations in adult astrocytic tumors and oligodendrogliomas," Neurology India, vol. 52, no. 2, pp. 228-232, 2004.

[69] B. Vogelstein, D. Lane, and A. J. Levine, "Surfing the p53 network," Nature, vol. 408, no. 6810, pp. 307-310, 2000.

[70] A. J. Levine, "p53, The cellular gatekeeper for growth and division," Cell, vol. 88, no. 3, pp. 323-331, 1997.

[71] N. Almog and V. Rotter, "An insight into the life of p53: a protein coping with many functions! Review of the 9th p53 Workshop, Crete, May 9-13, 1998," Biochimica et Biophysica Acta, vol. 1378, no. 3, pp. R43-R54, 1998.

[72] N. Akyuz, G. S. Boehden, S. Susse et al., "DNA substrate dependence of p53-mediated regulation of double-strand break repair," Molecular and Cellular Biology, vol. 22, no. 17, pp. 63066317, 2002.

[73] H. Ohgaki, "Genetic pathways to glioblastomas," Neuropathology, vol. 25, no. 1, pp. 1-7, 2005.

[74] S. Shiraishi, K. Tada, H. Nakamura et al., "Influence of p53 mutations on prognosis of patients with glioblastoma," Cancer, vol. 95, no. 2, pp. 249-257, 2002.

[75] D. N. Louis, M. P. Rubio, K. M. Correa, J. F. Gusella, and A. von Deimling, "Molecular genetics of pediatric brain stem gliomas. Application of PCR techniques to small and archival brain tumor specimens," Journal of Neuropathology and Experimental Neurology, vol. 52, no. 5, pp. 507-515, 1993.

[76] K. Watanabe, K. Sato, W. Biernat et al., "Incidence and timing of p53 mutations during astrocytoma progression in patients with multiple biopsies," Clinical Cancer Research, vol. 3, no. 4, pp. 523-530, 1997.

[77] E. W. Newcomb, H. Cohen, S. R. Lee et al., "Survival of patients with glioblastoma multiforme is not influenced by altered expression of p16, p53, EGFR, MDM2 or Bcl-2 genes," Brain Pathology, vol. 8, no. 4, pp. 655-667, 1998.

[78] J. J. Manfredi, "p53 and apoptosis: it's not just in the nucleus anymore," Molecular Cell, vol. 11, no. 3, pp. 552-554, 2003.

[79] C. Sarkar, S. Sinha, M. C. Sharma, R. Kumar, and V. S. Mehta, "Supratentorial glioblastoma in adults: identification of subsets and their clinical correlation," Brain Tumor Pathology, vol. 21, no. 1, pp. 7-12, 2004.

[80] H. Ohgaki, P. Dessen, B. Jourde et al., "Genetic pathways to glioblastoma: a population-based study," Cancer Research, vol. 64, no. 19, pp. 6892-6899, 2004.

[81] A. Kraus, M. W. Gross, R. Knuechel, K. Munkel, F. Neff, and J. Schlegel, "Aberrant p21 regulation in radioresistant primary glioblastoma multiforme cells bearing wild-type p53," Journal of Neurosurgery, vol. 93, no. 5, pp. 863-872, 2000.

[82] B. S. Chozick, J. C. Pezzullo, M. H. Epstein, and P. W. Finch, "Prognostic implications of p53 overexpression in supratentorial astrocytic tumors," Neurosurgery, vol. 35, no. 5, pp. 831-837, 1994.

[83] C. Sarkar, A. M. Ralte, M. C. Sharma, and V. S. Mehta, "Recurrent astrocytic tumours-a study of p53 immunoreactivity and malignant progression," British Journal of Neurosurgery, vol. 16, no. 4, pp. 335-342, 2002.

[84] M. Trepel, P. Groscurth, U. Malipiero, E. Gulbins, J. Dichgans, and M. Weller, "Chemosensitivity of human malignant glioma: 
modulation by p53 gene transfer," Journal of Neuro-Oncology, vol. 39, no. 1, pp. 19-32, 1998.

[85] O. Sembritzki, C. Hagel, K. Lamszus, W. Deppert, and W. Bohn, "Cytoplasmic localization of wild-type p53 in glioblastomas correlates with expression of vimentin and glial fibrillary acidic protein," Neuro-Oncology, vol. 4, no. 3, pp. 171-178, 2002.

[86] M. Miyagami and Y. Katayama, "Angiogenesis of glioma: evaluation of ultrastructural characteristics of microvessels and tubular bodies (Weibel-Palade) in endothelial cells and immunohistochemical findings with VEGF and p53 protein," Medical Molecular Morphology, vol. 38, no. 1, pp. 36-42, 2005.

[87] M. Mihara and U. M. Moll, "Detection of mitochondrial localization of p53," Methods in Molecular Biology, vol. 34, pp. 203-209, 2003.

[88] X. Chen, P. Wong, E. Radany, and Y. C. Wong, "HDAC inhibitor, valproic acid, induces p53-dependent radiosensitization of colon cancer cells," Cancer Biotherapy and Radiopharmaceuticals, vol. 24, no. 6, pp. 689-699, 2009. 


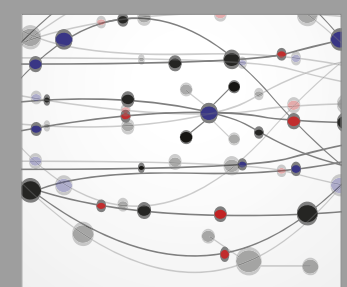

The Scientific World Journal
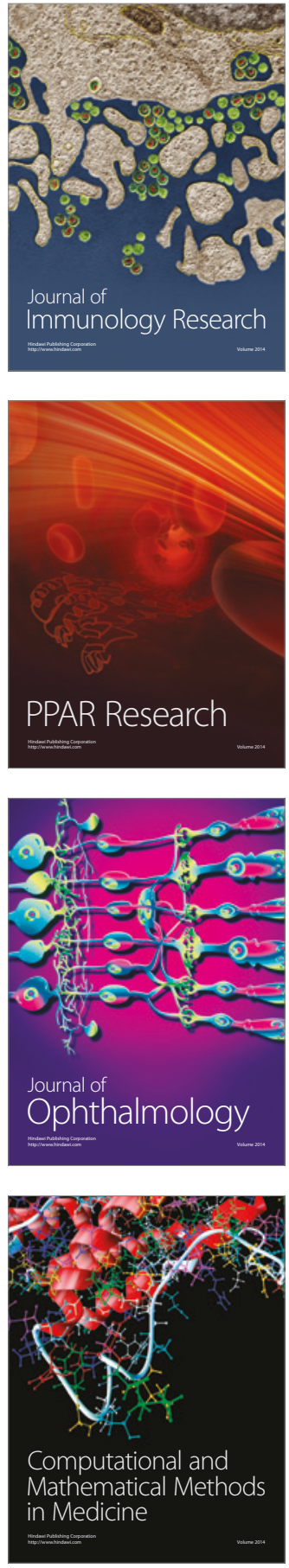

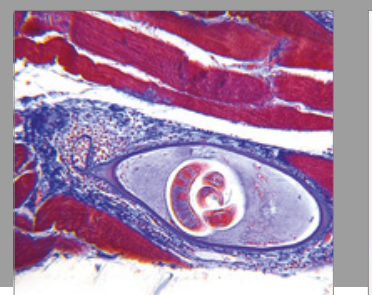

Gastroenterology Research and Practice
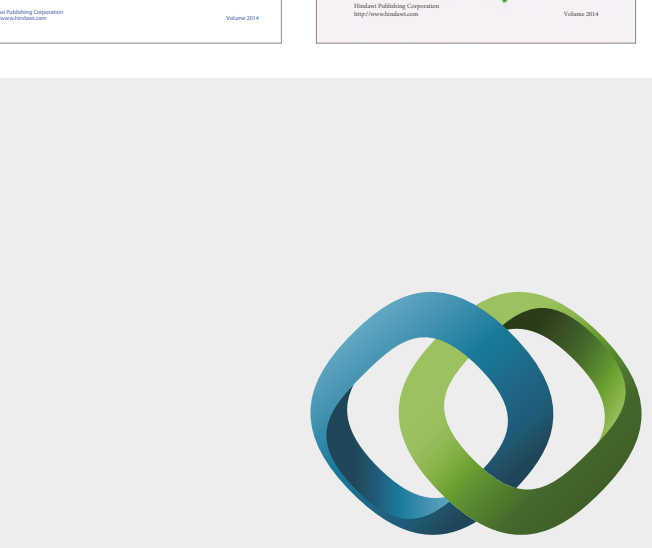

\section{Hindawi}

Submit your manuscripts at

https://www.hindawi.com
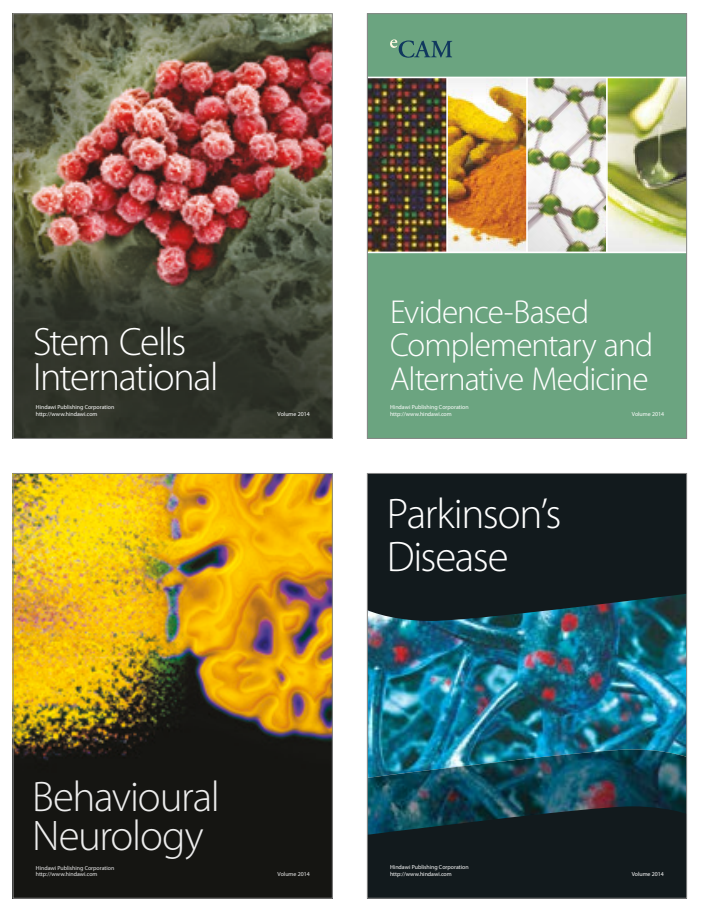
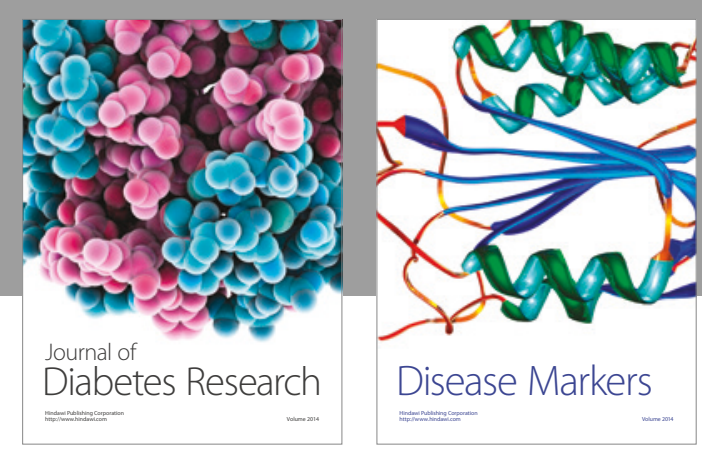

Disease Markers
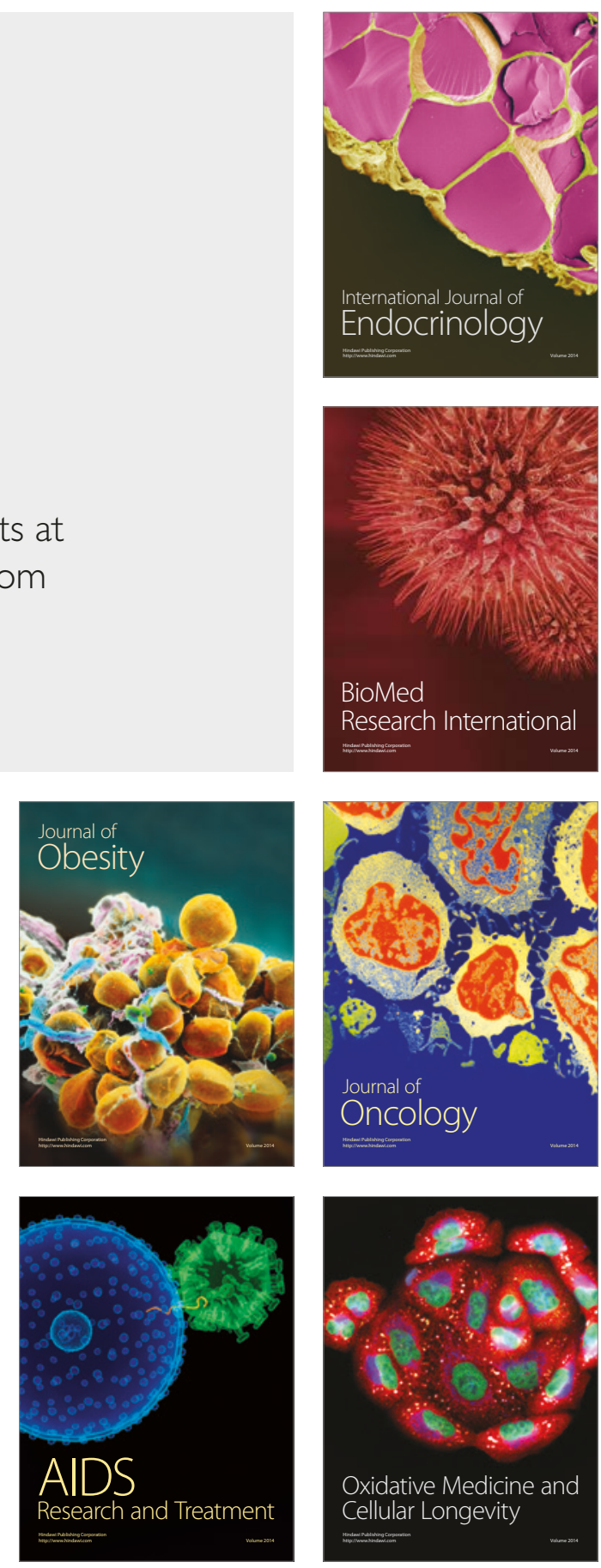